\title{
Interrogating the Historical and Cultural Context of Chinua Achebe's Things Fall Apart
}

\author{
Célestin GBAGUIDI*, Franck AHOSSOUGBE \\ Université d'Abomey-Calavi/République du Bénin
}

*Corresponding Author: Célestin GBAGUIDI, Université d'Abomey-Calavi/République du Bénin

\begin{abstract}
This research paper focuses on the historical and cultural context of the publication of Things Fall Apart (1958) by Chinua Achebe. Before the release of this work by Achebe, the vast majority of literary writings on Africa and its inhabitants were produced by Western writers who offered a distorted view of the black continent and of its inhabitants. In response to this misrepresentation of Africa and Africans in colonial novels, Chinua Achebe and other African writers stood out as the voice of a self-centered narrative of Africa and its inhabitants, narrated from an African perspective. These committed African nationalist writers committed themselves to the deconstruction of the primal, ape image of Africa and Africans. This analysis aims to show that by presenting a false image of Africa, the colonial novels had the merit of making Africans aware of the need to write their own history, thus triggering the publication of Things Fall Apart and the other literary productions of the time that started the fight for real recognition of African culture and traditions in the rest of the world. In a critical postcolonial approach, the study positions an unsatisfied Chinua Achebe at the heart of the battle for the acknowledgement of Igbo / African culture and traditions. It interprets Things Fall Apart as an Afro-centric image offered to the European reader for a change of outlook on African culture and traditions.
\end{abstract}

Keywords: colonial novel - racism - biased description - Africa - rehabilitation novel

\section{INTRODUCTION}

Africa is a continent of mysteries and paradoxes. It is full of surface and underground natural resources and of human resources, true assets for development and economic growth. Very early, the natural as well as the human resources of the African continent attracted Westerners; thus there is the rush for the African continent and a subsequent distressing plundering of its wealth with the deportation of millions of Africa's able-bodied people to the New World, Middle East, and Europe, organized by European powers. The enslaved Africans were forced into working as tillers, manual workers, servants, court jesters, cooks, hairdressers, musicians, and so forth. On this score, Marmer and Sow (2013) contend that in the expansionist aims of Europeans in the $15^{\text {th }}$ century, "Africans had been bereft of their humanity, culture, development and consequently, their history" (p. 50) [1].

Paradoxically, European explorers seemed or pretended not to know much about African customs. In the 1980s, for instance, Western history textbooks dealt little with Africa and Africans and the term Africa was hinted at in chapters covering European expansion, under titles such as "Discovery," "Imperialism," and "Decolonization," presented as short and superficial summaries, Tiemann (1982) [2].

Some of the European expansionists gave faithless and made up accounts of their journey in a way to entertain their people home. For Edward Said quoted by Klages (2012), "Western European explorers went to a place they called 'the Orient' and wrote descriptions of what they found there; Western European readers read these descriptions and understood 'the Orient' as something other than their own country and civilization" (p.61)[3]. These fanciful and demeaning narratives piled up year after year, twisting the truth about Africa and Africans. Some of these explorers produced creative writings which surprisingly met universal acclaim in their days. These European novels about Africa or foreign novels of Africa comprise Mister Johnson (1939) [4] by Joyce Cary, Heart of Darkness (1899) [5] by Joseph Conrad, and Graham Greene's The Heart of the Matter (1948) [6], to name only a few. Mister Johnson, by the Anglo-Irish man Joyce Cary, was said to be "the best novel ever written about Africa" (Achebe, 2003, p. 12) [7] despite the prejudiced stand the author has while portraying Africa and Africans. Though Conrad's Heart of Darkness plagues Africa and its people, a serious scholar 
described it as one of the greatest short novels in the English language, and it was read by all the students in the twentieth century literature courses in English Departments of American universities (Achebe 1977) [8].

Both Conrad and Cary, among others, succeeded in giving a bestial image of the black continent and its inhabitants. Africa and Africans, among others, were labelled savage, dark, cannibalistic, demonic, old children, cultureless, ugly, and merry makers. In a nutshell, such novels by non-Africans gave a distorted representation of Africa, triggering off the justified anger of the first generation of committed African writers. They felt the need of image re-appropriation, the need for works on black people, by black writers, and from a black perspective. Hurt in their self-esteem, they took their pens and started the battle for rehabilitation. On this score, one of the forerunners of Anglophone African literature, Chinua Achebe (1930-2013), released Things Fall Apart in 1958[9]. Alam (2010) posits that Achebe's motives for writing Things Fall Apart is to "correct a whole history of misrepresentations of his people and country in occidental discourse" (p. 40)[10]. Salami and Tabari(2018), in the same vein, contend that in Things Fall Apart, "the novelist has managed to provide an alternative discourse in order to attack the discursive dominance of the British colonizers [...] (p. 21)[11]. The purpose of this paper is to show that colonial novels gave a distorted image of Africa and its people, and that colonial novels sparked off the release of the first wave of postcolonial works among which Things Fall Apart, and thus made it possible for the African culture and traditions to be known to the world. Orientalism, Otherness and post-colonialism serve as the linchpin for the analysis.

\section{Historical ANTECEDENTS}

For long, Africa was thought by Western scholars to be a continent without civilization. Hugh Trevor Roper of the University of Oxford, in his course entitled "Africa and the West," makes this clear: "Perhaps in the future there will be some African history to teach. But at present there is none; there is only the history of Europeans in Africa. The rest is darkness and darkness is not the subject of history. There is only the unrewarding gyrations of barbarous tribes in picturesque but irrelevant corners of the Globe" (Lawal 2009, p. 2) [12].In the same stance as Roper, Hegel (1956) divides the inhabitants of the planet into two categories: historical peoples who are said to have contributed to the progress of mankind, and the non-historical peoples who have no hand in the growth of the human race. For him, Africa is non-historical (p. 99)[13].Moreover, on a visit to Senegal, the former French president, Nicolas Sarkozy(2007)condescendingly posits: "le drame de l'Afrique, c'est que l'homme africain n'est pas assez entré dans l' histoire"[14](the problem with Africa is that the African man has not yet made into history enough, translation ours). Analyzing the crucial role Africa occupies in German history textbooks and criticizing Hegel's stand on a non-historical Africa, Marmer and Sow (2013) make this bitter observation: "Induced into the Western cannon by Hegel, the notion of unhistorical Africa persists to the present day" (p. 49)[1].Conversely and thanks to archaeological findings, jaundiced assertions of Roper and Hegel's kinds have been demolished. In actual fact, nowadays, the anteriority of Africa's civilization over the others is acknowledged by unprejudiced scholars. For instance, it has been shown that alongside the Nile grew ancient civilizations. It is noteworthy that the Nile takes its source in the region of the Great Lakes, crosses Lake Victoria and flows over $6,000 \mathrm{~km}$ to Egypt. It crosses a lot of countries such as Uganda, parts of Kenya, The Soudan, and Egypt. Furthermore, the great contribution of Egypt/Africa to the formatting of Ancient writers like Thales, Pythagoras, and Plato is unquestionable. On this score, Roothan posits that:

The so-called "Greek miracle"-the idea that the ancient Greeks invented modern science and philosophy - is actually the result of Egyptian and other influences. Ancient writers themselves relate how Greek thinkers 'travelled to Egypt to learn in its temples'-among them Thales of Miletus and Pythagoras, who studied in the temples of Heliopolis, Memphis, and Thebes. And Plato himself, the great ancestor of Western philosophy spent thirteen years as a student in Heliopolis. Plato's vast influence on the Abrahamic, monotheistic theologies of the middle ages would then really be the passing on of ancient Egyptian (and hence black) theological views[15].

Contrary to Hegel who thought that Africa has no history, we ought to confess with James George in The Stolen Legacy that the Greek miracle is questionable: everything was taken from Egypt. Indeed, Urstad (2009) opines that: 
James' aim in Chapter One is to try to show that all the Ionian and Italian philosophers Pythagoras, Thales, Democritus, and so on - obtained their education from Egyptian priests or became familiar with the teachings of the so-called Egyptian Mysteries well before they settled down and published their philosophies. In effect, the author argues that what these philosophers were disseminating was really the thoughts and doctrines of these Egyptians [16].

For Lawal (2009), "Many European writers, for a long time, were of the opinion that since African societies were mainly non-literate, they were not worthy of study because history could not be properly studied in these societies, hence they had no history at all. In fact, to this school of thought, the continent contributed little or nothing to civilization" (p. 2) [12].Africa started with a brilliant history of writing. Contrary to the school of thought advocating the non-literacy of Africans before the European invasion, Bilé and Méranville (2017) opine that "l' Afrique noire précoloniale a connuplusieurssystèmesd'écriturebaséssurunegrammairevisuelleconstituée de signes graphiques et picturaux : arakoet nsibidiau Nigeria, giscandiau Kenya, mendéen Sierra Leone, vaïau Libéria, bamounau Cameroun, amhariqueen Éthiopie, bétéen Côte d'Ivoire » (p. 68)[17] (the pre-colonial black Africa experienced several writing systems, based on a visual grammar made up of graphical and pictorial signs: arako and nsibidi in Nigeria, giscandi in Kenya, mendé in Sierra Leone, vaï in Liberia, bamounin Cameroon, amharique in Ethiopia, bétéin Côte d'Ivoire, translation ours). In addition, Weissbach (1999) unveiled how Champollion discovered a sample of the Rosetta stone in Egypt. This stone bears a decree of the year 196 before Christ by Pharaoh Ptolemy V, written in two languages. Despite this brilliant beginning of writing in Africa, African literature began in an oral form, with various genres: songs, proverbs, stories, legends, myths, fables[18]. On the strength of the tremendous influence Egyptian civilization has had on world history, Rootha anpoints out that: "In addition, Afrocentric (or "Diopian") philosophy is gaining traction. This school of thought is named after the Senegalese scholar Cheich [sic] Anta Diop who shook up the learned world when he claimed, some sixty years ago, that the ancient Egyptians - the forebears of ancient Greek thoughtwere not semi-white, but black"[15].

The civilizing and expansionist missions brought a lot of Westerners to Africa. Some missionaries, for example, wanted to evangelize Africans and put an end to the slave trade but they faced harsh difficulties. As a matter of fact, Africa's climate, some of the continent's geographical features and diseases threatened and proved fatal to Europeans. Many of the white missionaries and explorers died of fever and malaria in their expansionist and evangelistic pursuits, as they were not used to the living conditions in the tropics. The natural hostility of the environment is one of the factors that account for the usually limited knowledge of Africa those Europeans self-proclaimed specialist of Africa had of the continent at the time. And this limited and fanciful knowledge they had of the continent reflected the biased narratives they offered. Apart of the few explorers who survived and made-true-to-life accounts of their stay, the others fathomed fancies without ever meeting real Africa, and published novels about Africa. All novels by non-Africans do not necessarily fall in the category of novels of Africa.

Though white, Nadine Gordimer (July's People)[19], Doris Lessing (The Grass is Singing)[20], and J. M. Le Clézio (The African)[21], to mention just a few, have not portrayed Africa and Africans hellishly in their creative works contrary to Henry Stanley. Indeed, Henry Stanley, a journalist working for the New York Herald, had been sent out to Africa by his editor. Stanley carried out important explorations particularly in the area of Congo. In 1891, he issued In the Darkest Africa [22] in which he describes Africa as a jungle of odd and strange beings he has never seen before. He depicts Africans as "cannibals" who eat one another and would not mind eating whoever comes their way. Stanley portrays Africa in a disgusting way; he talks of the uncivilized nature of Blacks who scream instead of talking. The covers of his books are very telling. Indeed, the cover of his creative writing published in 1891 is the picture of a continent with a black middle while the one of Through the Dark Continent [23] has an engraving of Stanley with a military uniform, on a boat, in a dense jungle. For Eagleton (2008), a novel seems to encompass both true and fictional events (p. 1)[24]. As such, the content of a novel may be purely fictitious or based on reality. European novels about Africa are mainly based on what Europeans thought of Africa, and do not necessarily stay in touch with reality. In his lecture, Margery Perham, a Research lecturer in Colonial Administration at the Oxford University Perham posits:"Until the very recent penetration by Europe the greater part of the continent (Africa) was without the wheel, the plough and transport-animals; almost without store 
houses or clothes except skins; without writing and so without history" (qtd. in Lawal, 2009, p. 2)[12]. European settlers knew very little about Africa. No wonder novels of Africa do not treat accurately Africa and Africans. For Echeruo (1973)[25], novels by non-Africans about Africa are characterized by fanciful alien settings, mainly portrayed to fit the whims of the community of their producers and their thirst for exoticism. These works mainly make a record or an interpretation of the life and situation of Africans for the entertainment of the readership within the author's native community. An image that encapsulates the dichotomy embodied in such novels is that of a letter one sends home from abroad. For Echeruo, the writer of a novel about Africa is like a folk reporter. And the longer the way, the bigger the lies. It is in the same vein that Gbaguidi (2012) contends that novels about Africa are the description of European travelers' thoughts about Africa and Africans. For him,

European settlers, imbued with prejudices and stereotypes, distorted the image of Africa and Africans in their writings. Those European travelers or tourists were not well informed about the realities of Africa or Africans. They used to consider Africa as the heart of darkness and Africans as children, liars, cannibals, savages, to name only a few such attributes (p. 19)[26].

In Heart of Darkness, Conrad portrays Africa as "the other world,"[4] or as Klages (2012) has put it "The Orient," [3] the exact opposite of Europe and therefore of 'civilization'. Strangely, in this type of novel, all that concerns Africa is painted in a negative way with clichés like: savage, hell, dark, wild, just to mention a few. Conrad sees in Africa a place where man's vaunted intelligence and refinement are looked down upon by triumphant bestiality (Achebe 1977).Africa served as a negative standard against which Europe rose to measure her humanity and humaneness. Conrad starts the book about Africa with an enticing description of his own native Thames thousands of kilometers far from the Congo River: it looks calm, resting and very attractive:

The Nellie, a cruising yawl, swung to her anchor without a flutter of the sails, and was at rest. The flood had made, the wind was nearly calm, and being bound down the river, the only thing for it was to come and wait for the turn of the tide. The sea reach of the Thames stretched before us like the beginning of an interminable waterway. In the offing the sea and the sky were welded together without a joint and in the luminous space the tanned sails of the barges... (p. 5)[8].

The actual story in the book takes place on the African river Congo where everything negative could be seen or come across till the end of the novella. The river Congo is then all the opposite of the Thames. With their'civilizing mission,' Europeans thought of Africa as a God forsaken place. On this score, the homodiegetic narrator points out: "We pounded along, stopped, landed soldiers; went on, landed custom-house clerks to levy toll in what looked like a God-forsaken wilderness, with a tin shed and flag-pole lost in it [...]" (Conrad, 1902, p.19)[4].The argument which most directly served the purpose of Africa's subjugation, and legitimized Europe's domineering view in its own eyes, is the bestialized image of the African created and reinforced in European fiction, the creation of "race" for the African Caliban, an image that calls Prospero to rescue. That bestialized Europe-made image of the African is so deeply rooted in the popular mind that almost two centuries of increased exchange have not succeeded in erasing it. Such a condescending or rather racist behavior is buttressed by the homodiegetic narrator's utterance in Conrad's novel: "Imagine him [Marlow] here - the very end of the world, dying like flies." (Conrad, 1902, p. 9)[4]. However, as Echeruo rightly points out, "Heart of Darkness is too lyrical a record of impressions, perhaps, to be representative of the manner of most European novels of Africa [...] which try to give the impression of fact and circumstance about the continent" (Conrad, 1902, p. 9)[4].

Africa was thought to be a place without civilization, "a place where big flies buzzed fiendishly, and did not sting, but stabbed" (Conrad, 1902, p. 26)[4]. This was what prompted white men to assign to themselves and by themselves the 'life-saving cause', the civilizing mission to cleanse the infectious place. Europeans were supposed to bring light to the Black who were in the 'darkest place'. The Black were in darkness and needed to be enlightened. Paradoxically, those who thought they were enlightened treated their fellow beings like farm animals and let them die as such. Going downhill, Marlow discovered the place where some Blacks have withdrawn to die:

They were dying slowly - it was very clear. They were not enemies, they were not criminals, they were nothing earthly now, - nothing but black shadows of disease and starvation, lying 
confusedly in the greenish gloom. Brought from all the recesses of the coast in all the legality of time contracts, lost in uncongenial surroundings, fed on unfamiliar food, they sickened, became inefficient, and then were allowed to crawl away and rest (Conrad, 1902, p. 24)[4].

The carefully crafted bestiality of the African, the demeaned and pitiful depictions fancied on these pages concurred to this conclusion thrown in an utterance as simple as this:"when one has to make correct entries, one comes to hate those savages - hate them to the death" (Conrad, 1902, p. 27)[4]. On the pretext of their superiority over Africans, white explorers developed a deadly hatred for natives. Going to the inner station, Marlow says about the fireman: "And between whiles I had to look after the savage who was fireman. He was an improved specimen; he could fire up vertical boiler. He was there below me, and, upon my word, to look at him was as edifying as seeing a dog in a parody of breeches and a feather hat, walking on his hind-legs" (Conrad, 1902, p. 52)[4].It turns out that the homodiegetic narrator does not really consider the fireman as a human being. The words: 'savage', 'specimen', 'seeing a dog', 'feather hat' and 'hind-legs' are words or expressions supporting the false idea that the creation of the Black is not totally completed, or rather Blacks are animals.

Arthur Joyce Lunel Cary is an Anglo-Irishman. In the years immediately following World War I, he served the British Empire on a territory Britain annexed and named Nigeria (Achebe 2003, pp. 30-31) [7]. Cary held several posts in Nigeria, including that of Magistrate and Executive Officer in Borgu, and thus wrote Mister Johnson. The setting of Mister Johnson is Nigeria. The most important events are set in Fada, a place with no inns or hotels, no convenience. Beyond Cary's line, we realize a kind of disgust he has for the land where he is living. This may account for his various stands about Fada. The narrator describes Fada town as a place with nothing attractive. Talking about the station of Fada, the narrator speaks as if he were disappointed at seeing thatched houses instead of nice bungalows. He describes it as follows:

The station has no bungalows. It consists of six old bush houses, with blackened thatch reaching almost to the ground, a fort and a police barracks, scattered at random, far apart from each other, on bare patches in the scrub. It is as if some giant had tossed down a few scraps of old rotten hay on a mangy lion skin, tufted with moth-eaten fragments of the hair and scarred with long, white seams (Cary, 1961, p. 7)[5].

Cary sees in Fada a hellish place, a place which does not favour progress at all - an antithesis of progress. He even says that Fada discourages progress of any kind (Cary, 1961, p. 7) [5]. In layman's terms, nothing good can come out of Nigeria in particular and Africa at large. Cary does mean what he is says. He does not use words at random but on purpose. It is as if he had a parcel of selected words, heralding a place good for savage animals. He uses words or expressions like: high jungle, swamps, and tsetse-flies. As a matter of fact, Cary has come to the comparison with dangerous animals. Besides, the animals in this jungle do not feel well. For the sake of argument, the comparison with the mangy lion skin is very telling.

Cary's disgust is not only aimed at Fada town but also at some people. In Home and Exile, Achebe says: "Cary has a very strong aversion to the people he is presenting to us. And to the towns and villages where these people live, where the action of his novel takes place" (p. 25)[7]. Johnson is a temporary clerk, still on probation, called upon emergency from a mission school. He is a third-class government clerk. He works in one of the most peaceful stations in the country. The narrator of the novel describes him as follows: "Johnson is not only a stranger by accent, but by colour. He is as black as a stove, almost pure negro, with short nose and full, soft lips. He is young, perhaps seventeen, and seems half-grown. His neck, legs and arms are much too long and thin for his small body, as narrow as a skinned rabbit's. He is loose-jointed like a boy, and sits with his knees up to his nose..." (Cary, 1961, p. 5)[5]. But the description the narrator makes of these males contrasts the laudatory depiction of females. His kindness and alacrity in describing Bamu, the ferryman's daughter, gives us a representation of the African beauty in body: "The ferryman's daughter, Bamu, was a local beauty, with a skin as pale and glistening as milk chocolate, high, firm breasts, round, strong arms. She could throw a twenty-foot pole with that perfect grace which was necessary to the act, if the pole was not to throw her [...]. What a pretty girl! [...]"(Cary, 1961, p. 5)[5].

In the narrative, Fada is portrayed as a jungle to the extent that nothing good can be expected from it. Worse still, in Cary's much praised creative writing, Africans are depicted to be uncivilized, cannibals, and nonentities. In the same stream of thought, beautiful though Bamu is, she is still a 
savage and an uncivilized girl who needs some civilization lessons. Her suitor, Johnson, says: "Oh, Bamu, you are only a savage girl here - you do not know how happy I will make you. I will teach you to be a civilized lady and you shall do no work at all" (Cary, 1961, p. 5)[5]. Interestingly, the way Cary handles the issue of bride price and marriage in his novel shows how sketchily he deals with African customs. As a rule, in most traditional African societies, it isthe responsibility of the groom's parents and relatives to find him a girl to marry or at least to start marriage negotiations with the prospective in-laws. Strangely, in Cary's novel under study, the protagonist, Johnson, after falling in love with the ferryman's daughter, starts marriage negotiation with Brimah, Bamu's father, with no regard for the African rule. African customs forbid suitors to go, alone, and straight forward, to his prospective in-laws to settle an issue of betrothal. Tactlessly, Johnson says to Brimah: "I want to marry Bamu. Have you decided how much you want?"(Cary, 1961, p. 14)[5]. Johnson, here, has, for sure, been affected by European ways of life As Ashcroft, Griffiths and Tiffin (2007) contend that: "Post-colonialism [...] deals with the effects of colonization on cultures and societies" (p. 168)[27], we can rightfully posit that the character Johnson is influenced and transformed by the colonizer's eyes. Furthermore, the patriarchal male character Johnson views his prospective wife as a saleable item and clumsily asks for the amount of money he shall pay to marry her. On this score, Gbaguidi (2018) opines: "One of the despicable sides of patriarchy is that it views women as marketable items" (p. 45)[28]. As far as the bride price is concerned, the narrator makes any African reader wonder if we are really in an African setting. It is a whole day bargaining between Johnson and Bamu's family, treating his in-laws to be savages and thieves. Johnson goes back home nearly naked, not for coming across raiders, but for giving his dress items as a pawn to secure the girl he wants to 'purchase.' After securing that purchase with the clothes he is wearing, "At five o'clock, naked except for a loincloth, he returns joyfully to arrange for his marriage" (Cary, 1961, p. 17) [5]. In fact, Joyce Cary's Mister Johnson seems to be the prototype of colonial novels about Africa carrying stereotypes of contemporary British colonial writings about Africa and Africans like the one positing that Africans buy wives (Pedler, 1951, p. 32)[29]instead of the symbolic customary bride price the groom gives to his in-laws to ask for their daughter's hand in marriage. Given all the aforementioned historical antecedents, what were Achebe's real motives for writing Things Fall Apart sixty years ago?

\section{From Colonial novels about Africa To Things Fall Apart}

As shown earlier, African literature in written form was by non-African writers in the beginning. For Strong-Leek (2001)[30], the traditional voice in African literature was driven by Europeans who represented Africa as a realm of 'negation'. Having read novels of Africa, mainly Heart of Darkness and Mister Johnson, Achebe comes to the conclusion that there is a power over narrative. Talking about Cary's Mister Johnson, Achebe said:

What Mister Johnson did do for me was not to change my course in life and turn me from something else into a writer [...]. But it did open my eyes to the fact that my home was under attack and that my home was not merely a house or a town but, more importantly, an awakening story in whose ambience my own existence had first begun to assemble its fragments into a coherence and meaning [...](Achebe 2003, P38) [7].

In colonial novels about Africa, we have "a confirmation of an attitude rather than an exploration of possibilities" (Echeruo, 1973, p.8)[25]. Basing on the first part of Achebe's Things Fall Apart, we can assert that novels of Africa really give a jaundiced image of Africa and its inhabitants. They basically aim at denigrating Africans so as to justify and give free reign to colonization. Being very critical about Cary's disparagement of Africa and Africans, Achebe points out: "We were ignorant of the hundreds of years of sustained denigration we and our home had been subjected to in order to make our colonization possible and excusable. If anyone had asked me in 1952 what I thought of Joyce Cary, I probably would have been quite satisfied to call him the generic pet name, imperialist"(Achebe, 2003, p. 33) [7].Padurang (2008) talks of Cary's Mister Johnson as a "racistcolonialist representation of Africa" (p. 343).

On the strength of such a biased representation of Africa and Africans in novels described as colonial novels about Africa, in the very years before the independences there was a real will of self-assertion in the colonies. In the 1950s, the emerging African elites, hurt in their pride, reacted to the horrendous stories about Africans and the black continent. They decided to redress the twisted image non-African writers made of Africa and its people from an African perspective. It then follows suit that colonial 
novels about Africa therefore drove African intellectuals to write rehabilitation novels in order to let their realities be known to the whole world. Through those creative writings, the African readers can see themselves in an African context and meanwhile the Western readership is authentically informed about what Africans and Africa are really like. Equally, an African reading for instance Cary's Mister Johnson realizes from the first pages that things and people are tagged as African, but in actual fact they are far from being African. And this can be noticed throughout the novel. For example, Cary thinks it is impossible for Africans to be good leaders. Indeed, Rudbeck's road is hardly finished when the narrator of the book ironically points out: "A chief in Africa can usually persuade his young men, or some of them, to go to a task, but he can rarely keep them there." (Cary, 1961, p. 101)[5]. One can easily notice that Cary hardly knows anything about African realities. As a matter of fact, in Achebe's novel published in 1958, the narrate can notice an imaginary society where Igbo people live harmoniously before the white man's intrusion with the subsequent breakup of their social fabric. The society designed by Achebe is a male-dominated one in which age, experience, and personal achievements - wealth accumulation through farming, title obtaining, being a great warrior or wrestler, masculinity -give male members the privileges conferred to the ruling class. In this vain, the protagonist, Okonkwo, is chosen to enter into the secret council of egwugwu. Okonkwo is a great wrestler, a hard-working farmer, a man with two titles and on top of it all, a great warrior. It is noteworthy that the egwugwu is that institution meant for administering justice within the community of Umuofia. It appears that Achebe's Things Fall Apart (1958) is a response to the colonial representation of Africa and Africans in literature, particularly in Joyce Cary's Mister Johnson (Strong-Leek, 2001)[30]. In the first part of his novel, Achebe reveals to the entire world that Igbo society is well structured and organized. Umuofia is the union of nine villages where there is a sound social and political organization before the arrival of the white man. Life in Umuofia is well structured, and follows a hierarchy. The 'Ndichie' or elders are the Fathers of Umuofia; then come the ancestors, and, on top, the gods. Kenalemang (2013) opines that:

Achebe's primary purpose of writing the novel is because he wants to educate his readers about the value of his culture as an African. Things Fall Apart provides readers with an insight of Igbo society right before the white missionaries' invasion on their land. The invasion of the colonizing force threatens to change almost every aspect of Igbo society; from religion, traditional gender roles and relations, family structure to trade (p. 4)[32].

As European explorers were looking for excuses to account for colonization, they worked themselves into letting their home people believe that Africa has no history, or civilization. Achebe (2003) elaborates on the colonial novels scheme thus:

In the end, I began to understand there is such a thing as absolute power over narrative. Those who secure this privilege for themselves can arrange stories about others pretty much where, and as, they like. Just as in corrupt, totalitarian regimes, those who exercise power over others can do anything. They can bring out crowds of demonstrators whenever they need them. In Nigeria it is called renting a crowd. Has Joyce Cary rented Joseph Conrad's crowd? (pp. 2425)[7].

In fact, in Mister Johnson, the protagonist Johnson, looks like a European but dressed up like an African in that his attitude is far from being African. The character Johnson is the classic depiction of the African character in fiction by colonial writers. He is a caricature of the African by non-African writers in the colonial era, and a mere bumbling idiot. On the off chance Johnson is African, he must be utterly influenced by colonization behaving like a European in an African setting. On this score, Ashcroft B., et al. (2007) [27] account for Johnson's culturally alienated behaviour by means of the contact he has had with the colonisers.For instance, Johnson's 'awkward' attitude towards his in-laws during his betrothal sounds non-African. Indeed, Johnson as a groom goes to Jirige alone to discuss marriage issues with his future father-in-law contrary to the African tradition. He starts the bride price bargaining with his in-laws, calls them names, and goes back home almost naked. By contrast, in Africa, before the advent of colonization, marriage was an agreement between two families. To redress things as represented in Cary's novel, in Achebe's Things Fall Apart, before the white man's intrusion into the Igbo society, the reader can clearly see that the groom's parents and relatives are at the front of the stage when it comes to marriage negotiations after their son has made the choice of his marriage partner; the male character Ibe has made room for his uncle and parents to start marriage negotiations with Obierika, his fiancé's father. 
Chinua Achebe in Home and Exile tells the story of the careless coq who turns down an invitation for all animals to attend a meeting. He pretended he had an urgent issue to attend to and enjoins his neighbors to extend his good wishes to the whole assembly and assure them he would abide by any decisions they make. As he was the only absent from the public square the day of the meeting, and that the meeting was about the continuous harassment of animals by humans for blood sacrifice, the animals unanimously agreed on offering the chicken to humans, which has remained so to this day. The morality of the story is that if the chicken had attended the meeting and made his own opinion known, he would never have become man's "primary sacrificial animal" $(14-15)$ [7]. The absence of his voice had him defined in the terms of the other animals as man's primary animal of sacrifice. What the story teaches us is that ability to tell stories is a power almost tantamount to the Genesis creative word: fiat lux. This "narrative power," when wielded by Europeans against Africans, silences our humanity, and becomes a deadly weapon that encapsulates Africans in a position which justifies Europeans' domination on Africans.

\section{CONCLUSION}

This paper has shown that with a view to reaching their imperialistic goals in Africa, European 'narrative power wielders' have written the black person into a subservient position, and relegated him/her, through pre-colonial novels, to an uncivilized ape-like savage. Heart of Darkness, Mister Johnson and their like really paint a false image of Africa. This research work helps us discover that colonial novels, depicting Africa and Africans in a biased way, have fuelled the muse of several committed African writers who tell the story about Africa and Africans from the lenses of Africans. The creation of the narratives of the self through storytelling is a duty if one does not want to perish as a people. Chinua Achebe, one of the forerunners of African literature, deconstructed the jaundiced portrayal of Joyce Cary's Nigeria and Nigerians in particular, and Africa and Africans, as a whole, by issuing Things Fall Apart in 1958 from the stance of the rich Igbo tradition and culture. Colonial novels about Africa starting the written narratives about Africa and its people, worked Africans into an inferior position which justified slavery and later, colonization. But African writers engaged in working their people out of those molds. In the literary history of Africa, it may be argued that the colonial novels about Africa called for a vigorous response found in African literature.

\section{REFERENCE}

[1] Marmer, E. \& Papa Sow (December, 2013). "African History Teaching in Contemporary German Textbooks: From Biased Knowledge to Duty of Remembrance.” In Yesterday \& Today, №10, pp. 49-76.

[2] Tiemann, D. 1982. "AfrikaimGeschichtsunterricht der Bundesrepublik Deutschland". In: Fürnrohr, W (ed). Afrikaim Geschichtsunterrichteuropäischer Länder. Von der Kolonialgeschichtezur Geschichte der Dritten Welt, Munich: pp. 135-151.

[3] Klages, M., (2012). Key Terms in Literary Theory. London: Bloomsbury Academic.

[4] Conrad, J. (1902/1994). Heart of Darkness. Penguin Popular Classics.

[5] Cary, J., (1961). Mister Johnson. London: Michael Joseph.

[6] Greene, B (1948). The Heart of the Matter. UK: Heinemann.

[7] Achebe, C. (2003). Home and Exile. Edinburgh: Cognate Book Ltd.

[8] (1977). Achebe, C. "An Image of Africa: 'Racism in Conrad's Heart of Darkness"” Massachusetts Review.18.

[9] Achebe, C., (1958). Things Fall Apart. London: H.E.B.

[10] Alam, F. (2010). "Reading Chinua Achebe's Things fall apart ecocritically." Bhatter College Journal of Multidisciplinary Studies." Vol. 1, N 1 , pp. 40-50.

[11] Salami, A. \&Tabari, B. H. (March 2018). "Things Fall Apart and Chinua Achebe's Postcolonial Discourse." International Journal on Studies in English Language and Literature (IJSELL). Volume 6, Issue 3, pp. 19-28. ISSN 2347-3126 (Print) \& ISSN 2347-3134 (Online). http://dx.doi.org/10.20431/23473134.0603004

[12] Lawal, S. (2009). Africa and the West. Ed. Osita A. Agbu. Lagos: National Open University of Nigeria. ISBN: 978-058-978-3.

[13] Hegel, G.W.F. 1956 (1830). The Philosophy of History. New York: Dover.

[14] Sarkozy, N. (November 2007). «Le discours de Dakar de Nicolas Sarkozy », Le Monde.

[15] Roothan, A. "Plato Studied in Africa: The Case for Culturally Inclusive Philosophy." In http://hipporeads. com/plato-studied-in-africa-the-case-for-culturally-inclusive-philosophy/ Retrieved on August 8, 2018. 
[16] Urstad K. (2009). "James, George G. M., Stolen Legacy: The Egyptian Origins of Western Philosophy." (Book Review). In Kritike Volume Three Number Two (December 2009) pp. 167-70

[17] Bilé, S. and Méranville, M. (2017). Les Noirs: Clichés et préjugés de l'époque coloniale à nos jours. l'Archipel.

[18] Weissbach, M. M. (1999)“Unlocking the Civilization of Ancient Egypt: How Champollion Deciphered the Rosetta Stone.” In FIDELIO Magazine. https://www.schillerinstitute.org/fid_9701/993_champollion.html. Retrieved on August 6, 2018

[19] Gordimer, N (1981). July's People. London: Jonathan Cape.

[20] Doris L. (1950). The Grass is Singing. New York: Ballantine Books.

[21] Le Clézio, J. M. G. (2004). L'Africain (The African). Paris : Mercure de France.

[22] Stanley, H. (1890). In Darkest Africa. New York: Charles Scribner's Sons.

[23] Stanley, H. (1879). Through the Dark Continent. New-York: Harper and Brothers.

[24] Eagleton, T., (2008). Literary Theory. USA: Minnesota University Press.

[25] Echeruo, M.J.C., (1973). Joyce Cary and the Novel of Africa. London: Longman Group limited.

[26] Gbaguidi, C. (2012). Morality and social instability in West African literature: a reading of selected novels by Chinua Achebe and AyiKwei Armah (Doctoral Dissertation). Abomey-Calavi: UAC.

[27] Ashcroft, B., Griffiths, G. and Tiffin, H. (2007). Post-Colonial Studies: The Key Concepts. New York: Routledge.

[28] Gbaguidi, C. (2018). "The Representation of the African Woman in Male-Dominated Society: A Study of Chinua Achebe's Things Fall Apart and Amma Darko's Beyond the Horizon." In International Journal of Arts and Humanities (IJAH)Vol. 7 (2), S/No 25, APRIL, 2018: 40-48 ISSN: 2225-8590 (Print) ISSN 2227-5452 (Online) DOI: http://dx.doi.org/10.4314/ijah.v7i2.6

[29] Pedler, F. J. (1951). West Africa. London: Methuen \& Co.

[30] Strong-Leek, L., (2001). "Reading as a Woman: Chinua Achebe Things Fall Apart and Feminist Criticism.” African Studies Quarterly, Volume 5, Issue 2.

[31] Padurang, (2008). "Chinua Achebe and the African Experience in Things Fall Apart”. New York: Norton.

[32] Kenalemang, L.M., (2013). "Things Fall Apart: An analysis of pre and post-colonial Igbo society". Karlstads Universitet.

\section{AUTHORS' BIOGRAPHY}

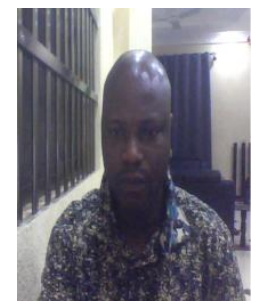

Dr Célestin Gbaguidi is a senior Lecturer of Anglophone African Literature at Abomey-Calavi University in Benin. He holds a Doctorate degree in Anglophone African Literature from the same University. His research interests are mainly gender issues, good governance in the political arena, and youth migration in literature.

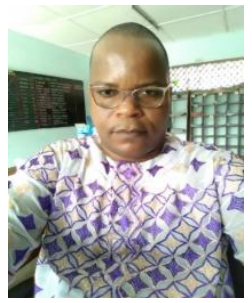

Mr Franck Ahossougbé is a doctoral student in Anglophone African Literature, at the Graduate School of the Faculty of Arts and Social Sciences at Abomey-Calavi University in Benin Republic. He holds a post-graduate diploma (DEA) in Anglophone African Literature from the same University. He is currently working on "Colour Bar and the Depiction of Africans by Non-African Writers: A Study of Selected Works by Joseph Conrad, Joyce Cary, Nadine Gordimer and Doris Lessing" for his doctoral dissertation.

Citation: Célestin GBAGUIDI, Franck AHOSSOUGBE. "Interrogating the Historical and Cultural Context of Chinua Achebe's Things Fall Apart" International Journal on Studies in English Language and Literature (IJSELL), vol 6, no.8, August 2018, pp. 30-38. doi:http://dx.doi.org/10.20431/2347-3134.0608004.

Copyright: () 2018 Authors. This is an open-access article distributed under the terms of the Creative Commons Attribution License, which permits unrestricted use, distribution, and reproduction in any medium, provided the original author and source are credited. 